\title{
Onisimus turgidus (Sars, 1879) (Amphipoda, Uristidae), an overlooked amphipod from sea anemones in Northern Norway
}

\author{
Wim VADER ${ }^{1}$, Jan Roger JOHNSEN ${ }^{2} \&$ Anne Helene S. TANDBERG ${ }^{3, *}$ \\ ${ }^{1}$ Tromsø Museum, UiT - The Arctic University of Norway, NO 9037 Tromsø, Norway. \\ ${ }^{2}$ Ekkerøya, NO 9800 Vadsø, Norway. \\ ${ }^{3}$ University museum of Bergen, University of Bergen, PO box 78, NO 5020 Bergen, Norway. \\ *Corresponding author: anne.helene.tandberg@uib.no \\ ${ }^{1}$ Email: wim.vader@uit.no \\ 2Email: janrogerjohnsen@hotmail.com \\ ${ }^{1}$ urn:1sid:zoobank.org:author:92E60D63-E003-466F-A155-F526B851B9CB \\ ${ }^{2}$ urn:1sid:zoobank.org:author:4499FF63-F9B4-4314-B9D0-826B2966E505 \\ ${ }^{3}$ urn:1sid:zoobank.org:author:26BB8830-FA36-4F87-B3DD-0C28C7F0C504
}

\begin{abstract}
Two Norwegian uristid amphipods, obligate associates of sea anemones, have for a long time been confused sub nomine Onisimus normani Sars, 1890. In reality this species only occurs in south Norway, while the north-Norwegian material belongs to O. turgidus (Sars, 1879), described from the Barents Sea and for a long time forgotten. This paper fully illustrates both species, gives a key, and provides data on their distribution and ecology.
\end{abstract}

Keywords. Sibling species, Crustacea, species complex.

Vader W., Johnsen J.R. \& Tandberg A.H.S. 2020. Onisimus turgidus (Sars, 1879) (Amphipoda, Uristidae), an overlooked amphipod from sea anemones in Northern Norway. European Journal of Taxonomy 724: 34-50. https://doi.org/10.5852/ejt.2020.724.1155

\section{Introduction}

In his great monograph on Norwegian amphipods G.O. Sars (1891) described the uristid species "Onesimus normani, Schneider, ms" on the basis of a single specimen, found in a sample of $O$. edwardsi (Krøyer, 1846), "probably from some place in Finnmark". He noted (op. cit.: 106): "The present new species was first detected by Mr Schneider in the neighbourhood of Tromsø, Finnmarken (...) I have had an opportunity of seeing his detail drawings of the species." Unfortunately, neither Schneider's drawings nor his specimens seem to be extant. Vader $(1967,1970)$ discovered that Onisimus normani Sars, 1891 lives in the gastrovascular cavity of the sea anemone Bolocera tuediae (Johnston, 1832) and studied this association in the vicinity of Bergen, W Norway; the amphipods enter the host as 2-3 mm long juveniles in autumn, and leave the sea anemone as $8-9 \mathrm{~mm}$ long adults 18 months later. Strangely, ovigerous females have as yet never been found anywhere. (The specimen from Oslofjord described by Sars (1895) as having "reddish ova in the marsupial pouch" in reality carries the isopod 
parasite Parapodascon Hansen, 1916 (Vader, unpubl. obs.: Parapodascon sp.), which also commonly infested O. normani in the Bergen population (Vader 1967)). Onisimus Boeck, 1871 thus spends a large part of its life-cycle inside the sea anemone and it is almost immune to the proteolytic enzymes in the gastrovascular cavity that quickly kill and digest other amphipods (Vader \& Lønning 1973). A later study showed that these amphipods do not, as originally assumed, feed primarily on the semi-digested remains of the prey of the sea anemone, but instead on the mesenterial filaments of the host itself (Moore et al. 1994).

When the first author moved from Bergen to Tromsø and again found reddish Onisimus specimens inside sea anemones there, it was assumed at first that they too must be $O$. normani, a species originally described from this area (Vader 1975). A few points of difference between the west and north Norwegian animals were nevertheless noted. Although both amphipods were reddish, there was a clear difference in hue between the two, and in addition the animals in the population of Ullsfjorden $\mathrm{N}$ of Troms $\varnothing$ were primarily found in the sea anemone Actinostola callosa (Verrill, 1882) and only to a lesser degree in Bolocera tuediae. The question was tackled by Johnsen (2001) in an unpublished MSc thesis, and he came to the unexpected conclusion that the N Norwegian material does not belong to $O$. normani, which is largely confined to southern Norway, with the northernmost record in Andfjorden in Nordland, but instead represents Onisimus turgidus (Sars, 1879), a species further described by Sars in his report on the crustaceans of the Northern Norwegian Sea Expedition (Sars 1885), on the basis of a few specimens collected in the Barents Sea, in fact also with sea anemones. This species was for a long time almost forgotten; it was not mentioned at all in Sars' monograph on the Norwegian amphipods (Sars 18901895), and although it figures in Stephensen's "The Amphipoda of Northern Norway and Spitsbergen" (Stephensen 1935-1942), it is misrepresented in his key to Onisimus species and is impossible to identify correctly with this key. Johnsen (2001) studied presumed $O$. normani samples from different parts of the world (W Atlantic Ocean, E Siberia) and came to the conclusion that they all are closer to $O$. turgidus than to O. normani, but that both the W Atlantic and the E Siberian material show some peculiarities, that may lead to these entities needing to be described as separate species. At least the W Atlantic material is also associated with sea anemones (Vader 1967). Johnsen's drawings of O. turgidus (Johnsen 2001) are here reproduced in Figs 4-10. They are both re-illustrations of specimens from the type material (from the Barents Sea) (Figs 4-6) and material from Ullsfjord (Figs 7-10). This species has recently also been reported once more from the Barents Sea (Bryazgin 1997; Lyubina et al. 2014, again as O. normani; Zimina et al. 2019); Johnsen has seen some of Bryazgin's material.

\section{Material and methods}

This study is based on a combination of museum material (Arctic University Museum of Tromsø (TSZCrnumbers) and the Natural History museum Oslo (F-numbers) and material collected in recent field studies (deposited at the Arctic University Museum of Tromsø). All historic material was initially preserved in formaldehyde before being transferred to $70 \%$ ethanol for storing at the museums. The material sampled for the Johnsen thesis work was directly fixed in seawater-diluted ethanol (75\%), before being transferred to freshwater-diluted $70 \%$ ethanol for longterm storage at the Tromsø Museum (now known as the Arctic University Museum of Tromsø). All material was initially studied and sorted using stereo microscope, dissected and mounted in rose Bengal-stained polyvinyl-lactophenol on microscope slides for morphological examination. All drawings were made using a camera lucida mounted on a Leica compound microscope fit with a camera lucida for pencil drawings. Initial pencil drawings were subsequently inked using the methods described by Coleman $(2003,2009)$ using Adobe Illustrator CC2019.

\section{Abbreviations}

$$
\begin{array}{ll}
\mathrm{A} & =\text { antenna } \\
\mathrm{Ep} & =\text { epimeral plate }
\end{array}
$$




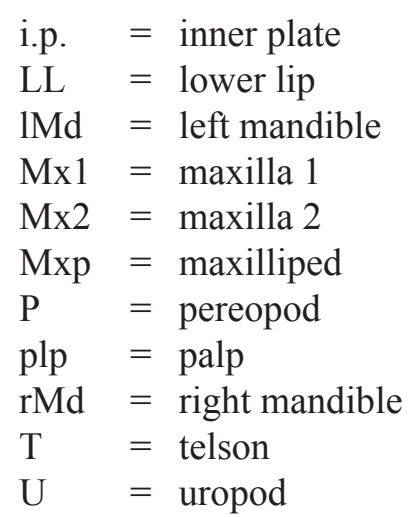

\title{
Results
}

\author{
Order Amphipoda Latreille, 1816 \\ Class Malacostraca Latreille, 1802 \\ Family Uristidae Hurley, 1963 \\ Genus Onisimus Boeck, 1871
}

\section{Key to the 'normani-group'}

The 'normani-group' within Onisimus is characterized by a partly cleft telson, a completely constricted uropod 2, and a peculiar $1^{\text {st }}$ epimeral plate, with an anterodistal hook (Vader et al. 2005). The group consists of $O$. normani, $O$. turgidus, and 2 or 3 taxa closely related to $O$. turgidus, but strongly deviating in the arrangement of the setal teeth on the outer plate of maxilla 1. Material belonging to these taxa has been found in the W Atlantic Ocean, near Greenland and in the NW Pacific (Johnsen 2001). Most (or possibly all) species in this group appear to be obligate associates of sea anemones, a trait absent in all other Onisimus species. In Norwegian waters there are two species in this group, O. normani in W Norway north to Andfjorden, and O. turgidus in N Norway and the Barents Sea. They can be distinguished as follows:

1. Pereopod 1 palm oblique, propodus subrectangular. Uropod 2 inner ramus with small setae in constriction; uropod 1 outer ramus without spines on inner margin

Onisimus normani Sars, 1891

- Pereopod 1 palm strongly oblique, propodus triangular. Uropod 2 inner ramus with large spine in constriction; uropod 1 outer ramus with spines on inner margin .... Onisimus turgidus (Sars, 1879)

\section{Onisimus normani Sars, 1891}

Figs 1-3

Onesimus normani (Schneider ms) Sars, 1891: figs on pl. 36-2.

Onesimus normani - Sars, 1895: 105.

Onisimus normani - Stephensen 1923: 48; 1935: 38. - Vader 1967: 286, figs 2-3; 1975: 38; 1983 : 144. — Vader \& Lønning 1973: 29. — Lowry \& Stoddart 1993: 169. — Johnsen 2001: 49, fig. 17.

non O. normani - Stephensen 1923: 48. - Shoemaker 1930: 11. - Vader 1975: 38. - Moore et al. 1994: 206. — Vader \& Krapp-Schickel 1995: 65. — Bryazgin 1997: 99. — Lyubina et al. 2014: 246. (All these references $=$ O. turgidus (Sars, 1879). $)$ 


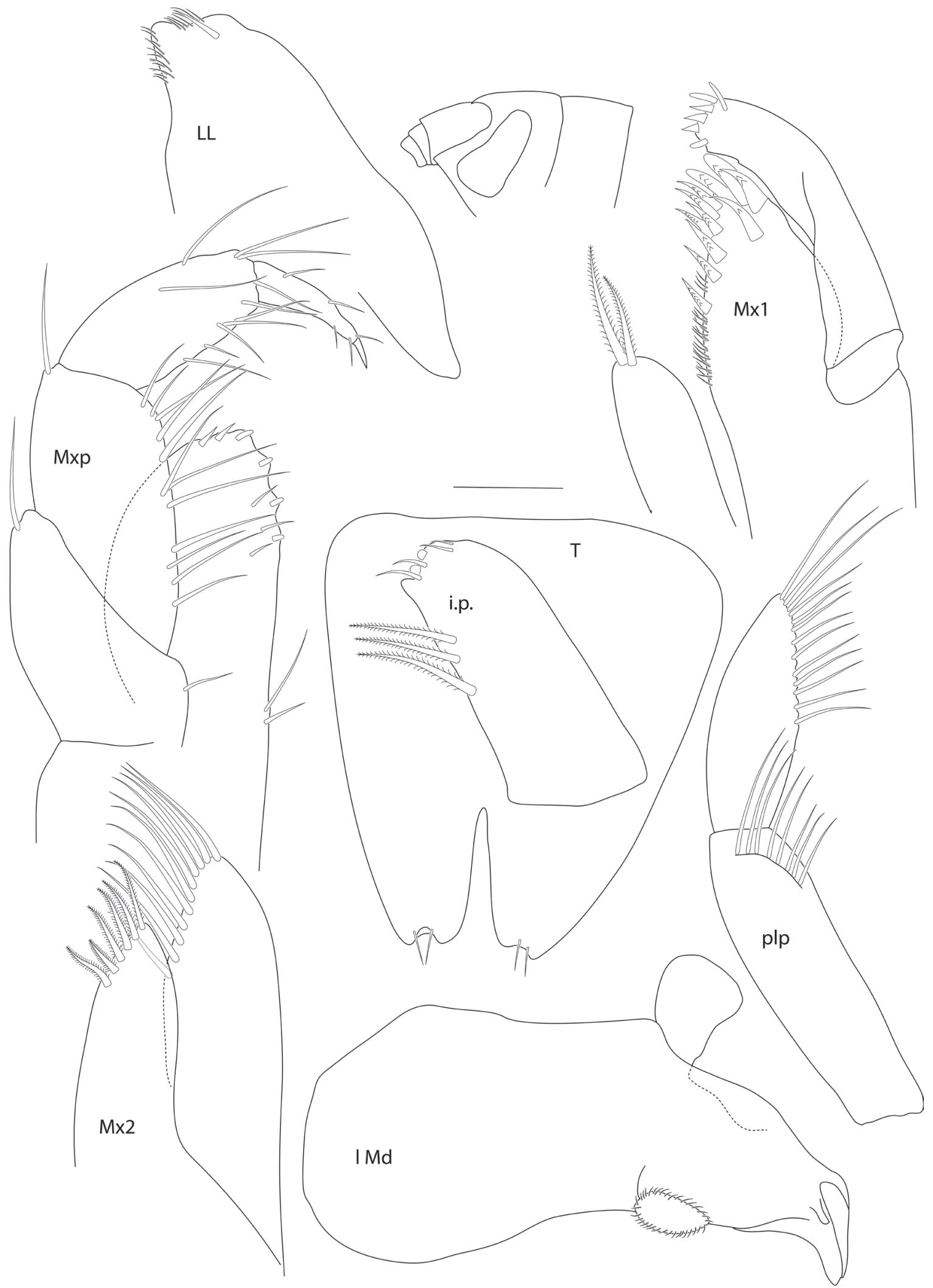

Fig. 1. Onisimus normani Sars, 1890,, $10 \mathrm{~mm}$, Korsfjorden, Norway (TSZCr8659). Head, mouthparts (l mandible, lower lip, maxilla 1, maxilla 2, maxilliped), telson. Abbreviations: see Material and methods. Scale bars $=0.1 \mathrm{~mm}$. 


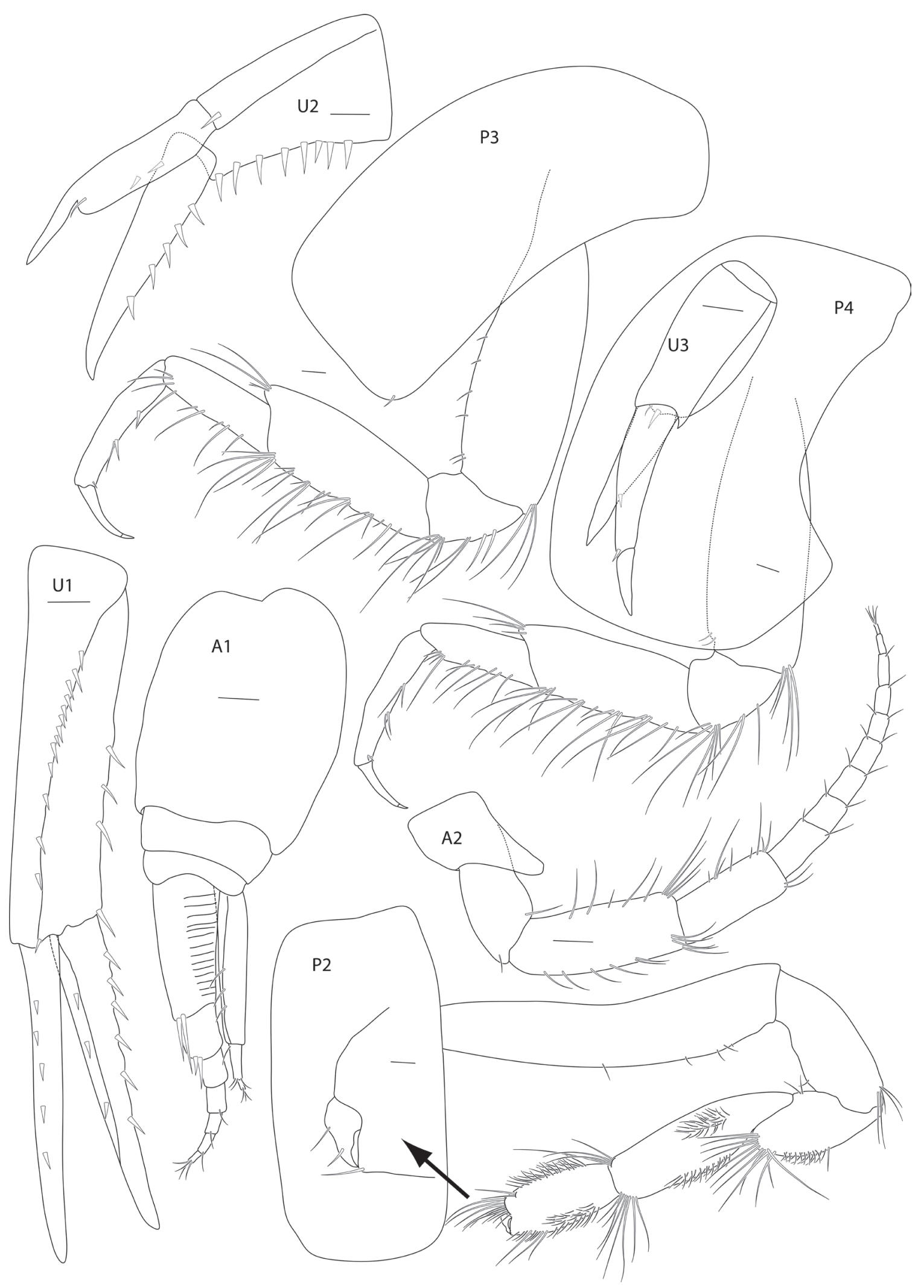

Fig. 2. Onisimus normani Sars, 1890,,+ 10 mm, Korsfjorden, Norway (TSZCr8659). Pereopods 2, 3 and 4, uropods 1, 2 and 3, antenna 1 and 2. Abbreviations: see Material and methods. Scale bars = $0.1 \mathrm{~mm}$. 


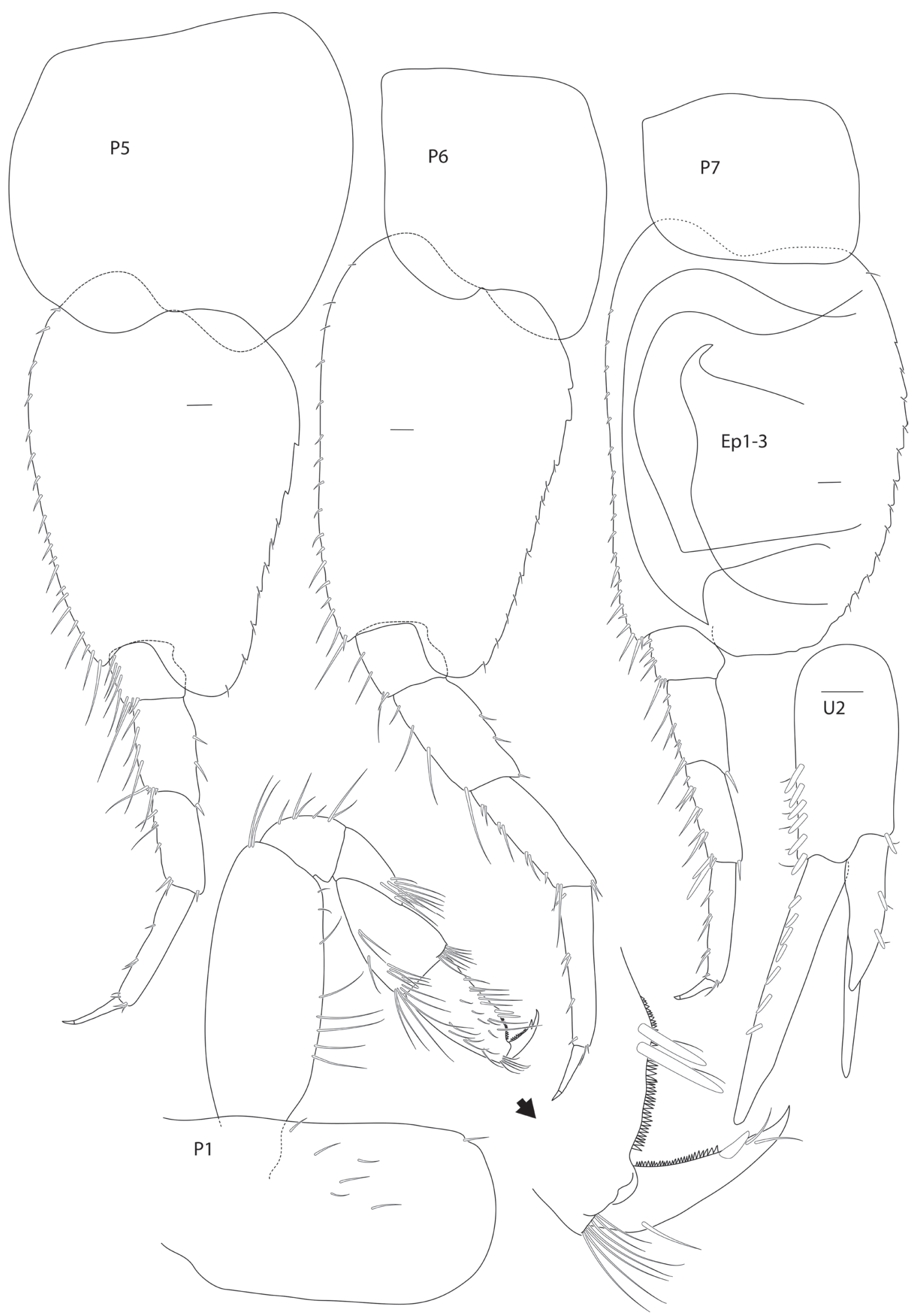

Fig. 3. Onisimus normani Sars, 1890, $\uparrow, 10 \mathrm{~mm}$, Korsfjorden, Norway (TSZCr8659). Pereopods 1, 5, 6 and 7, uropod 2, epimeral plates 1-3. Abbreviations: see Material and methods. Scale bars $=0.1 \mathrm{~mm}$. 


\section{Material examined}

NORWAY • 1 ( $(10 \mathrm{~mm})$; Korsfjorden; $680 \mathrm{~m}$ depth; 1968; Wim Vader leg.; from Bolocera tuediae; TSZCr8659 (Figs 1-3) 1 1 immature $(8 \mathrm{~mm}$ ); same collection data as for preceding; TSZCr8659 - 1 spec.; Raunefjorden; 240 m depth; 1968; Wim Vader leg.; from Bolocera tuediae; TSZCr8628 • 1 spec.; Korsfjorden; 680 m depth; 1968; Wim Vader leg.; from Bolocera tuediae; TSZCr8623• 1 spec.; same collection data as for preceding; TSZCr8624 2 specs; same collection data as for preceding; TSZCr9320 • 7 specs; Andfjorden; 69¹8'42" N, 16²3'24" E; 498 m depth; 1 Jul. 1997; Wim Vader leg.; from Bolocera tuediae; TSZCr12962

\section{Distribution}

Although there are many records of $O$. normani in the amphipod literature, all except those from Southern Norway in reality are either $O$. turgidus or taxa very closely related to that species (Johnsen 2001). Johnsen mentions a record from Andsfjorden at $69^{\circ} \mathrm{N}$ (material in Tromsø Museum): otherwise this species has only been recorded from the Oslofjord and a number of localities in W Norway (Vader 1967). Onisimus normani appears to be an obligate associate of the sea anemone Bolocera tuediae, and it has only exceptionally been found in other sea anemones (Vader 1967, 1975), although it is well able to survive also in other sea anemone hosts in the laboratory (Vader \& Lønning 1973).

Onisimus turgidus (Sars, 1879)

Figs 4-10

Anonyx turgidus Sars, 1879: no 13.

Onisimus turgidus - Sars, 1885: 147, pl. xii, fig. 5, comb. nov. (described as sp. nov.). - Lowry \& Stoddart 1993: 169. — Johnsen 2001: 60, fig. 21. —Zimina et al. 2019: 871.

Onisimus normani - Stephensen 1923: 48. — Shoemaker 1930: 11. — Vader 1975: 38. — Moore et al. 1994: 206. — Vader \& Krapp-Schickel 1996: 65. — Bryazgin 1997: 99. — Lyubina et al. 2014: 246.

(These are all not $O$. normani, but $O$. turgidus.)

\section{Material examined}

NORWAY • 1 q, syntype (15 mm); Barents Sea; 72 $53^{\prime} \mathrm{N}, 21^{\circ} 51^{\prime} \mathrm{E}$; $408 \mathrm{~m}$ depth; 30 Jul. 1878; G.O. Sars leg.; stn 323 (trawl), Norwegian North sea Expedition; $1.5^{\circ} \mathrm{C}$; silt.; F1764 (Figs 4-6) - 1 $(10 \mathrm{~mm}$ ); Kuberget Ullsfjorden; $100 \mathrm{~m}$ depth; Sep. 1974; Wim Vader leg.; from Actinostola callosa; TSZCr8573. (Figs 7-10) • 1 spec.; Ullsfjorden; from Actinostola callosa; TM IX-95 • 2 specs; Ullsfjorden; 69³9'48" N, 1945'18" E; 106 m depth; 28 Apr. 1995; Wim Vader leg.; from Actinostola callosa; stn JohanRuud 255-95; TSZCr14488 • 21 specs; Ullsfjorden; Jun. 1995; Wim Vader leg.; from Actinostola callosa; stn Hyas 6-95; Arctic University Museum of Tromsø 1 spec., Finnkroken; 50 60 fathoms depth; 1900; J. Sparre Schneider leg.; TSZCr1171.

\section{Distribution}

Johnsen (2001) studied samples of presumed Onisimus normani from different parts of the world, and concluded that they all (except the ones from S Norway) belonged in the turgidus species complex; unfortunately there was not sufficient material available to be able to revise this entire complex. The type material was collected from the Barents Sea and it has been collected from this area several times since (Bryazgin 1997; Lyubina et al. 2014, sub nomine O. normani; Zimina et al. 2019). Material from $\mathrm{N}$ Norway (Ullsfjorden) is quite similar to the type material, but the animals are smaller, $10 \mathrm{~mm}$ against $14 \mathrm{~mm}$ for the type. No fully adult or ovigerous specimens of $O$. turgidus have been found as yet, similar to the situation in $O$. normani. Onisimus turgidus also spends most of its life inside a sea anemone and like $O$. normani, likely leaves the host when almost adult. 


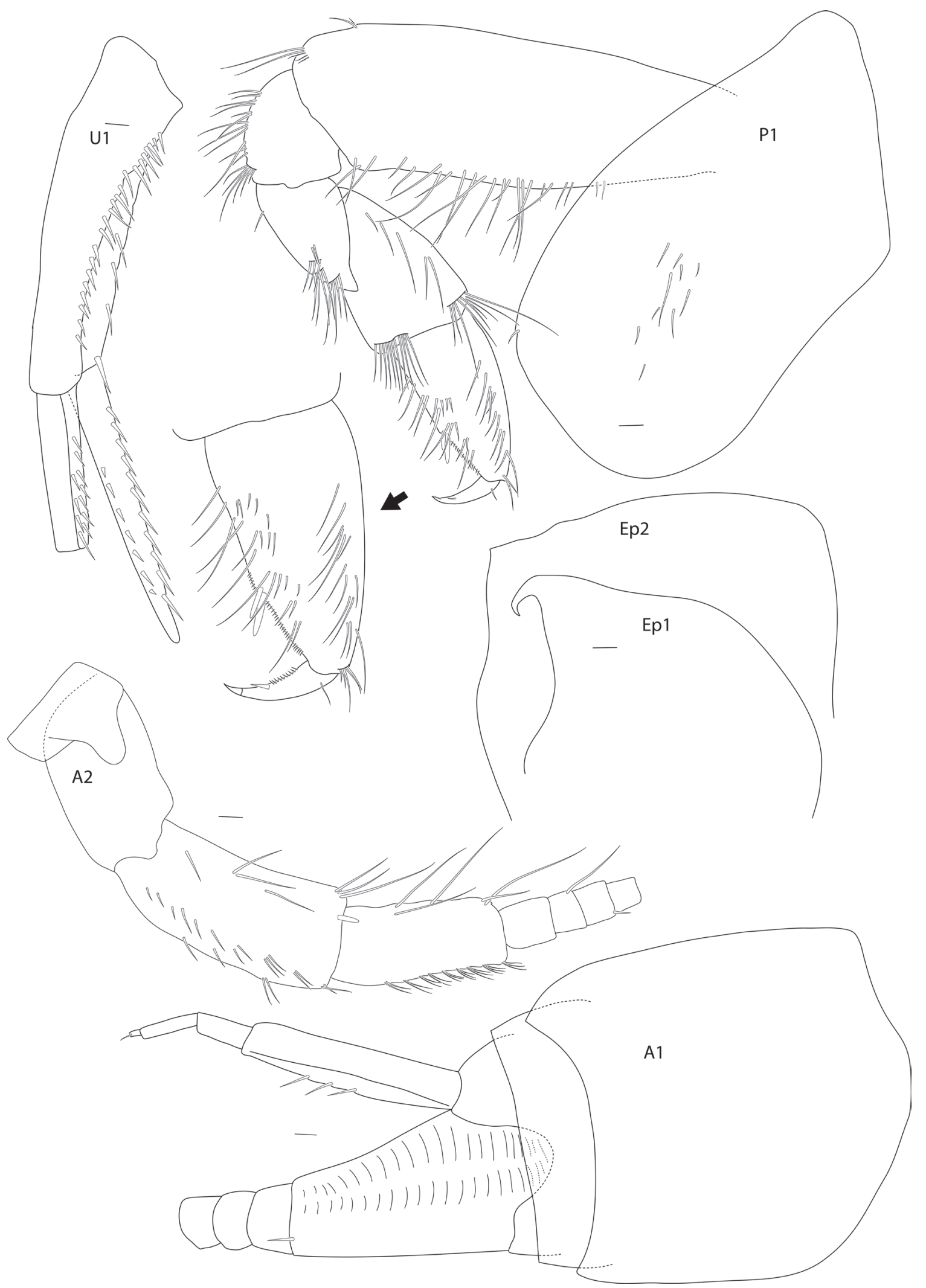

Fig. 4. Onisimus turgidus (Sars, 1879), syntype,,$+ 15 \mathrm{~mm}$, Barents Sea (F1764). Antenna 1-2, pereopod 1, epimeral plates 1-2, uropod 1. Abbreviations: see Material and methods. Scale bars $=$ $0.1 \mathrm{~mm}$. 


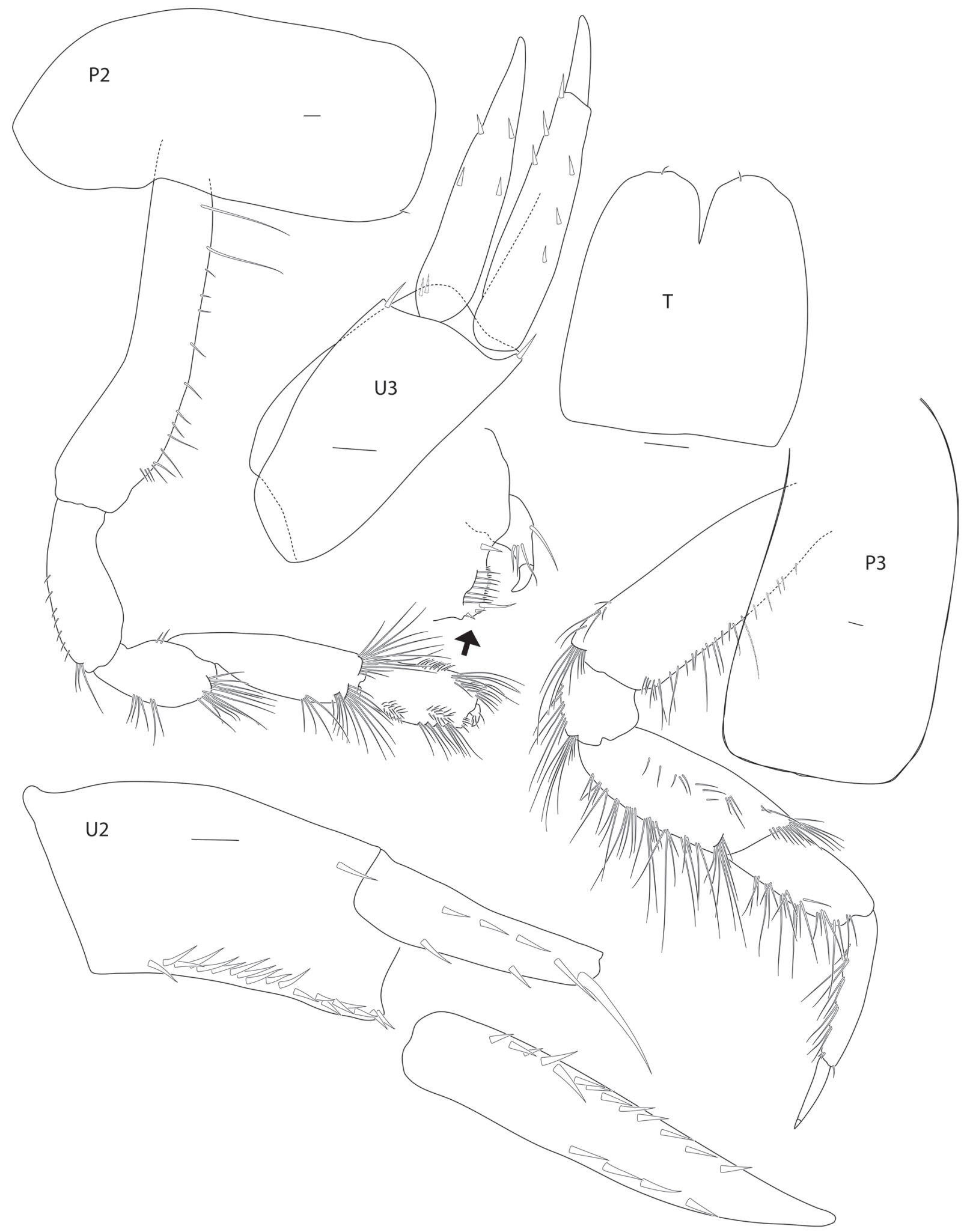

Fig. 5. Onisimus turgidus (Sars, 1879), syntype, $q, 15 \mathrm{~mm}$, Barents Sea (F1764). Pereopods 2-3, uropods 2-3, telson. Abbreviations: see Material and methods. Scale bars $=0.1 \mathrm{~mm}$. 


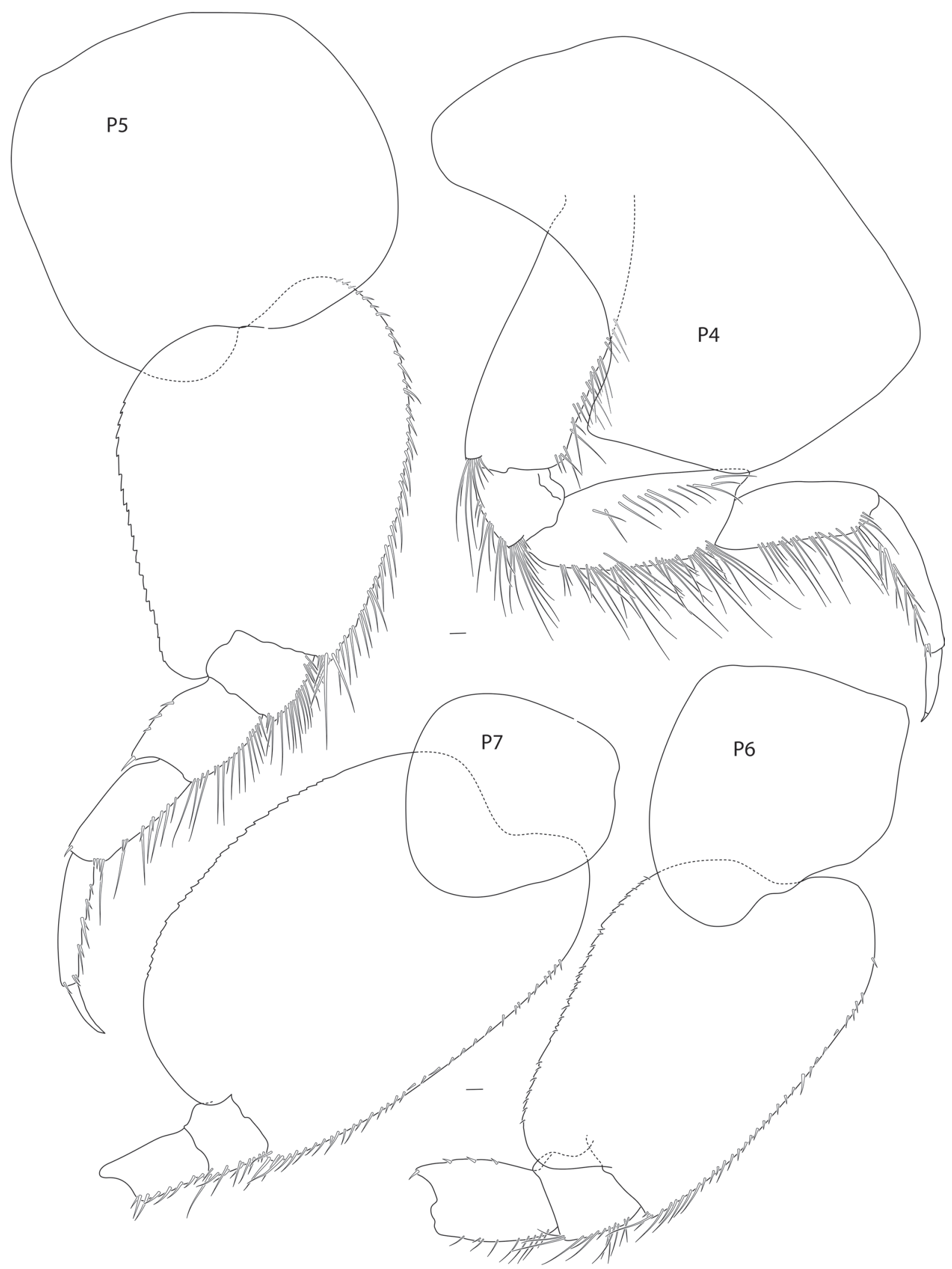

Fig. 6. Onisimus turgidus (Sars, 1879),,, $15 \mathrm{~mm}$, Barents Sea (F1764). Pereopods 4-7. Abbreviations: see Material and methods. Scale bars $=0.1 \mathrm{~mm}$. 


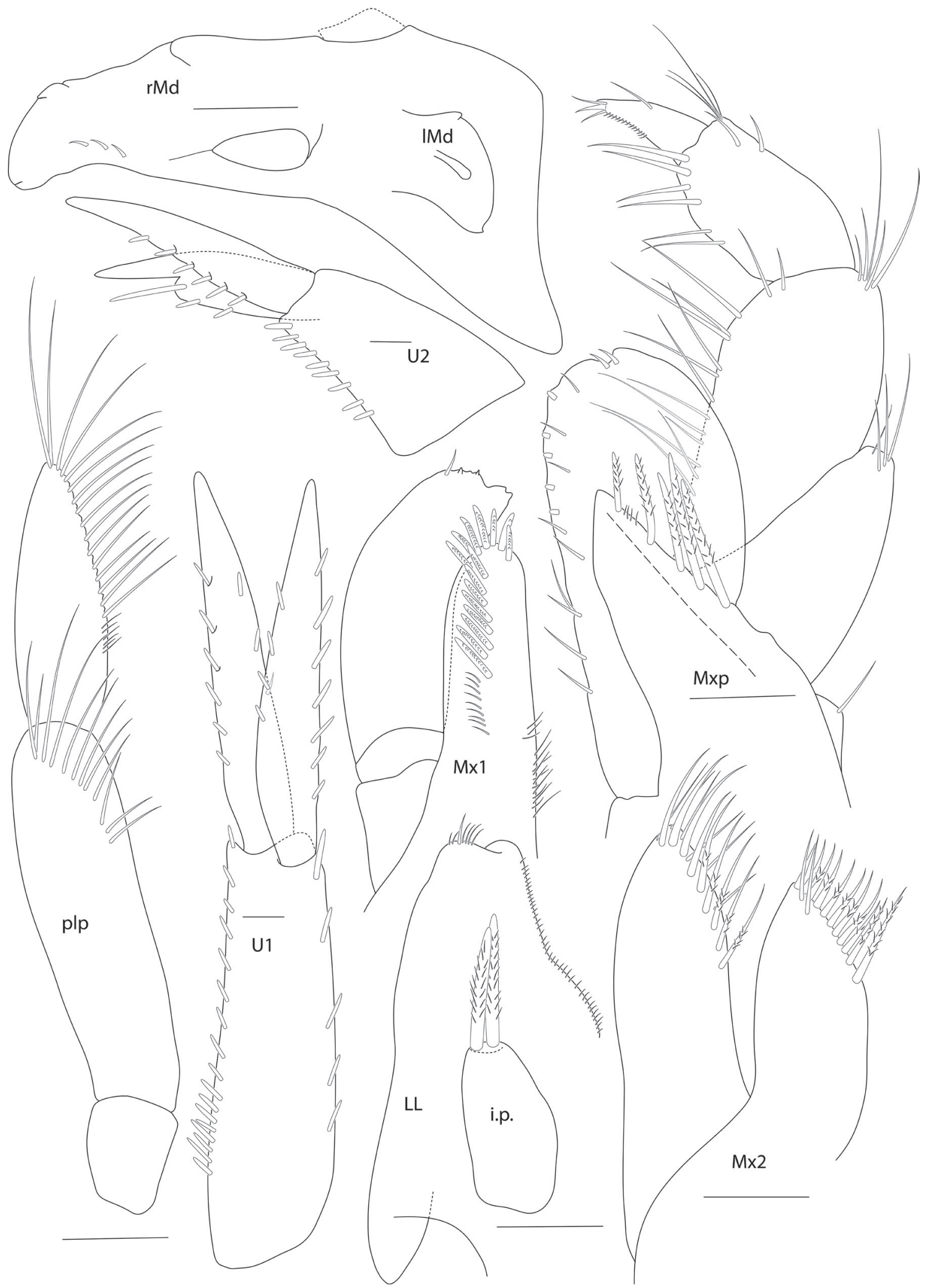

Fig. 7. Onisimus turgidus (Sars, 1879),, , $10 \mathrm{~mm}$, Ullsfjorden (100 m depth) (TSZCr8573). Mouthparts ( $\mathrm{r}$ and 1 mandible, lower lip, maxilla 1, maxilla 2, maxilliped), uropod 1. Abbreviations: see Material and methods. Scale bars $=0.1 \mathrm{~mm}$. 


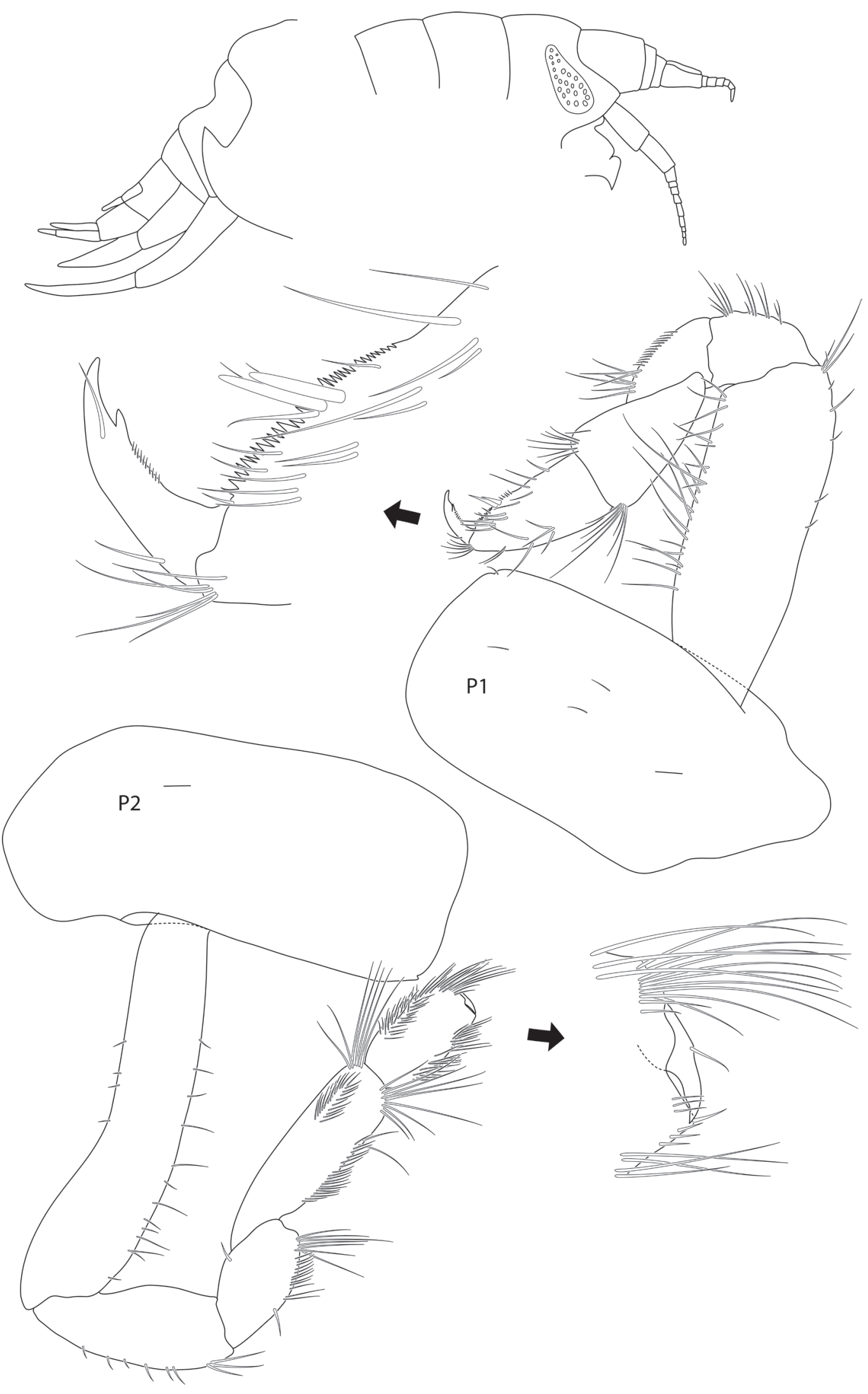

Fig. 8. Onisimus turgidus (Sars, 1879),,$+ 10 \mathrm{~mm}$, Ullsfjorden (100 m depth) (TSZCr8573). Head, backbody, pereopods 1-2. Abbreviations: see Material and methods. Scale bars $=0.1 \mathrm{~mm}$. 


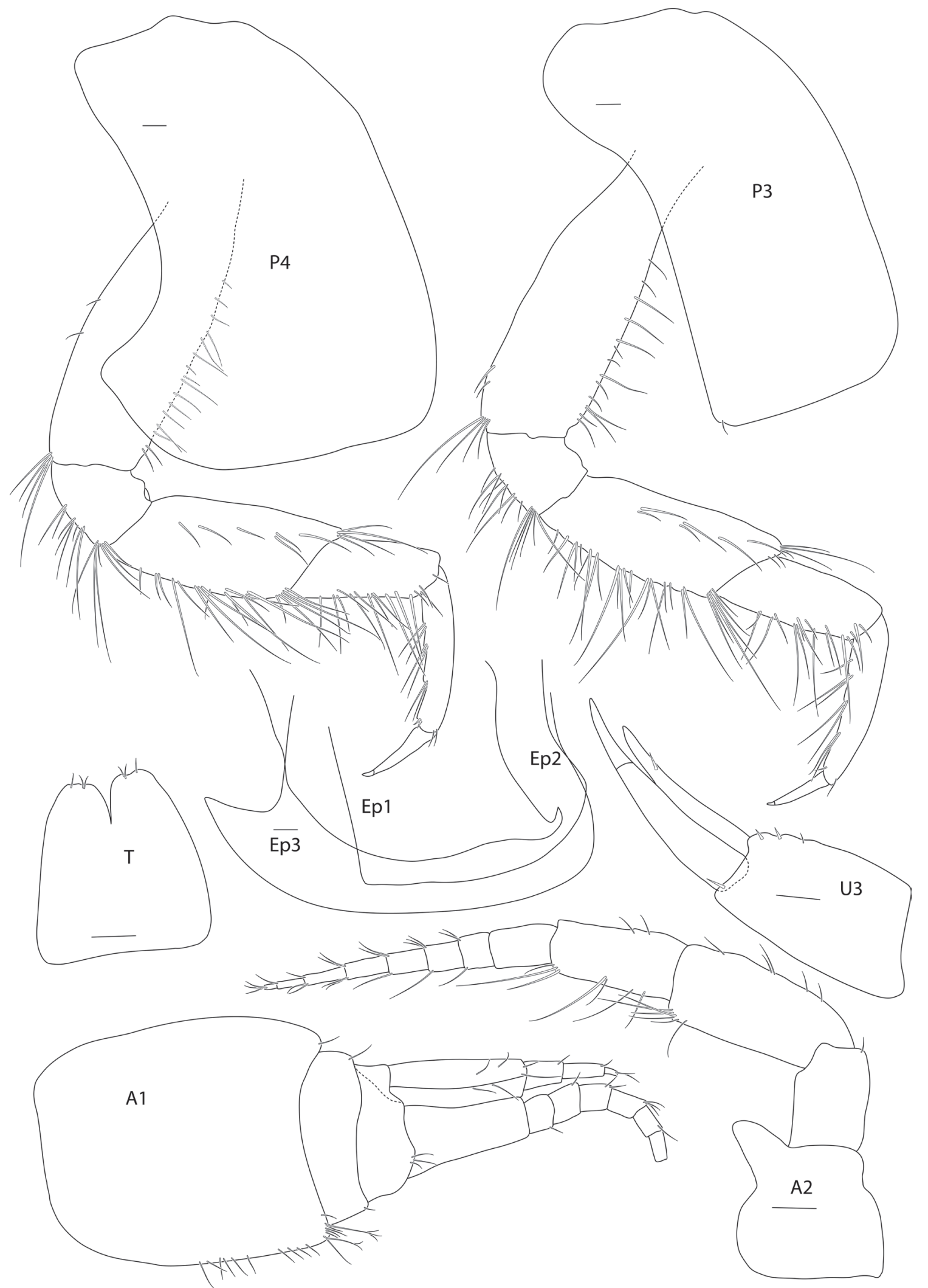

Fig. 9. Onisimus turgidus (Sars, 1879),, $10 \mathrm{~mm}$, Ullsfjorden (100 m depth) (TSZCr8573). Antennae $1-2$, pereopods 3-4, epimeral plates $1-3$, uropod 3, telson. Abbreviations: see Material and methods. Scale bars $=0.1 \mathrm{~mm}$. 


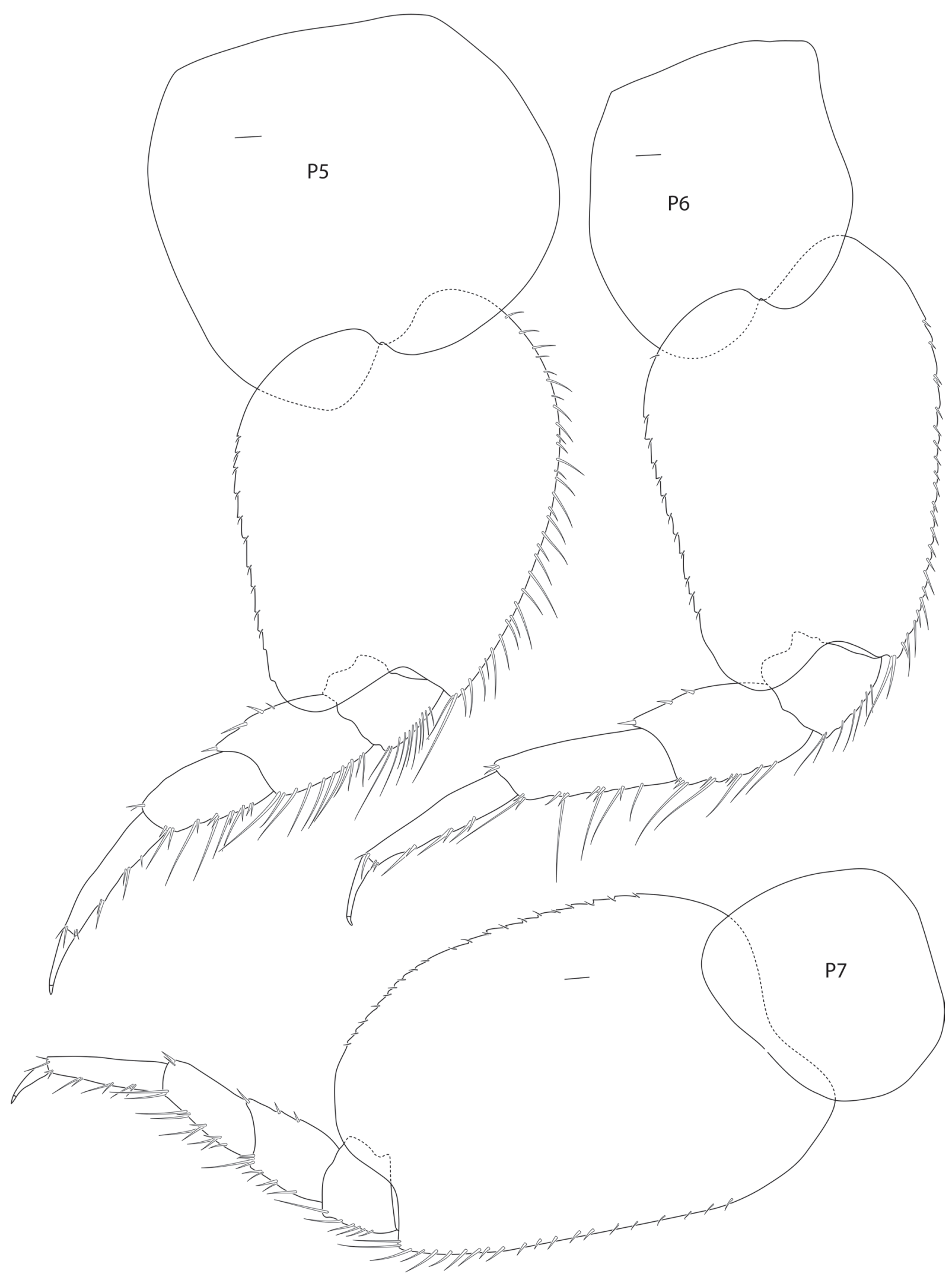

Fig. 10. Onisimus turgidus (Sars, 1879), $+10 \mathrm{~mm}$, Ullsfjorden (100 $\mathrm{m}$ depth) (TSZCr8573). Pereopods 5-7. Abbreviations: see Material and methods. Scale bars $=0.1 \mathrm{~mm}$. 


\section{Biology}

Onisimus turgidus appears to be an obligate associate of sea anemones for most of its life-cycle. The preferred host of Onisimus turgidus in N Norway is Actinostola callosa. The numbers vary quite a lot from year to year (Moore et al. 1994; Vader \& Krapp-Schickel 1996: table 2, sub nom. O. normani) but the species is never numerous even there: in 714 specimens of Actinostola Verrill, 1883 from Ullsfjorden 116 specimens of $O$. turgidus were found, an infection percentage of 0.16 amphipods per host. There is a significant positive correlation between the size of the Actinostola hosts and the number of Onisimus found inside: in the large sample of January 1974 sea anemones of 10-50 g wet weight contained 0.03 amphipods per host, those of 60-100 g 0.54 and the few of 100-150 g 3.00. Actinostola callosa in Ullsfjorden also is the host of another amphipod species, Stenothoe brevicornis Sars, 1883, that likewise feeds on host tissue, but this amphipod lives on the outside of the host, among the tentacles (Moore et al. 1994; Vader \& Krapp-Schickel 1996).

Onisimus turgidus in Ullsfjorden is also sometimes found inside Bolocera tuediae, the almost exclusive host of O. normani in S Norway (Vader 1973), but here it is even less common than in A. callosa: in 297 specimens of Bolocera Gosse, 1860 from Ullsfjorden only 14 specimens of Onisimus were found ( 0.05 amphipods per host). The parasitic isopod Parapodascon sp. that is quite common on $O$. normani in S Norway, has also been found a few times on $O$. turgidus from the Ullsfjord.

\section{Discussion}

The discovery that all Onisimus material collected in N Norway and identified as $O$. normani in reality belongs to $O$. turgidus, causes a nomenclatural problem, since Sars (1891) states that his material came from a sample of $O$. edwardsii (Krøyer, 1846) (a species that probably does not occur in S Norway, although in older literature it has been reported a few times) from 'somewhere in Finnmarken' (which at the time included also Troms province). Sars' description and illustrations clearly show 'the real $O$. normani', i.e., the species from W Norway, and not $O$. turgidus, which is the sole species in this group in 'Finnmarken', and Sars' specimen therefore most probably came from S Norway somewhere, even though in 1890 he emphatically declared that he had not yet found O. normani there. Similar problems with Sars' type specimens have occurred before: d'Udekem d'Acoz (2004) discussed the case of Bathyporeia sarsi Watkin, 1938, where Sars material of 'B. robertsoni Spence Bate, 1862', on which Watkin based his $B$. sarsi, has Sørøya, Finnmark, as type locality; this species has never been found in Norway north of the Oslofjord (d'Udekem d'Acoz loc. cit.)

\section{Acknowledgements}

The authors thank Prof. Valery Bryazgin, Petrozavodsk, for sharing his Barents Sea material of Onisimus turgidus with us. The Norwegian Biodiversity Information Centre SpeciesProject_16_18 ("NorAmph2") has financed the collaboration between WV and AHST. Robert Bergersen (Arctic Universitymuseum Troms $\varnothing$ ) and Åse Wilhelmsen (Natural History museum Oslo) are thanked for kind help with information from their respective collections databases. Two anonymous reviewers and the editor are thanked for their thorough and very helpful work.

\section{References}

Bryazgin V. 1997. Diversity, distribution and ecology of benthic amphipods (Amphipoda, Gammaridea) in the Barents Sea sublittoral. Polish Polar Research 18: 89-106.

Coleman C.O. 2003. "Digital inking": how to make perfect line drawings on computers. Organisms, Diversity \& Evolution 3 (4): 303-304. https://doi.org/10.1078/1439-6092-00081 
VADER W. et al., On two close Onisimus (Crustacea, Amphipoda) from Norway

Coleman C.O. 2009. Drawing setae the digital way. Zoosystematics and Evolution 85 (2): 305-310. https://doi.org/10.1002/zoos.200900008

Johnsen J.R. 2001. The taxonomy of Onisimus. MSc thesis, University of Tromsø, Norway.

Lowry J.K. \& Stoddart H.E. 1993. The Onisimus-problem (Amphipoda, Lysianassoidea, Uristidae). Zoologica Scripta 22: 167-181. https://doi.org/10.1111/j.1463-6409.1993.tb00349.x

Lyubina O.S., Bryazgin V.F. \& Raznovskaya S.V. 2014. The composition and distribution of benthic amphipods (Crustacea: Amphipoda) in the southern Barents Sea. Russian Journal of Marine Biology 40: 241-254. https://doi.org/10.1134/S1063074014040063

Moore P.G., Rainbow P.S. \& Vader W. 1994. On the feeding and comparative biology of iron in coelenterate-associated gammaridean Amphipoda (Crustacea) from N. Norway. Journal of Experimental Marine Biology and Ecology 178: 205-231. https://doi.org/10.1016/0022-0981(94)90037-X

Sars G.O. 1879. Crustacea et Pycnogonida nova in itinere $2^{\text {do }}$ et $3^{\text {tio }}$ expeditionis norvegicae anno 1877 \& 78 collecta (Prodromus descriptionis). Archiv for Mathematik og Naturvidenskaber 4: 427-476.

Sars G.O. 1885. Crustacea I. Norwegian North Atlantic Expedition 1876-1878 6 (14): 1-280. https://doi.org/10.5962/bhl.title.2168

Sars G.O. 1890-1895. An Account of the Crustacea of Norway, with short Descriptions and Figures of all the Species. Vol. 1. Amphipoda. Alb. Cammermeyers Forlag, Christiania and Copenhagen. https://doi.org/10.5962/bhl.title.1164

Schneider J.S. 1924. Tromsøsundets amphipoder, isopoder og cumaceer. Tromsø Museums Arshefter 47 (8): $1-73$.

Shoemaker C.R. 1930. The lysianassid amphipod crustaceans of Newfoundland, Nova Scotia, and New Brunswick in the United States National Museum. Proceedings of the United States National Museum 77: 1-19. https://doi.org/10.5479/si.00963801.77-2827.1

Stephensen K. 1923. Crustacea Malacostraca. V (Amphipoda I). The Danish Ingolf Expedition 3 (8): $1-100$.

Stephensen K. 1935. The Amphipoda of N. Norway and Spitsbergen with adjacent waters. Tromsø Museums Skrifter 3: 1-140.

d'Udekem d'Acoz C. 2004. The genus Bathyporeia Lindström, 1855, in western Europe (Crustacea: Amphipoda: Pontoporeiidae). Zoologische Verhandelingen Leiden 348: 1-162.

Vader W. 1967. Notes on Norwegian marine amphipods 1-3. Sarsia 29: 283-294.

https://doi.org/10.1080/00364827.1967.10411089

Vader W. 1970. Amphipods associated with the sea anemone, Bolocera tuediae, in western Norway. Sarsia 43: 87-98. https://doi.org/10.1080/00364827.1970.10411171

Vader W. 1975. The sea anemone, Bolocera tuediae, and its copepod parasite, Antheacheres duebeni, in northern Norway. Astarte 8: 37-39.

Vader W. 1983. Associations between amphipods (Crustacea: Amphipoda) and sea anemones (Anthozoa, Actiniaria). Memoirs of the Australian Museum 18: 141-153.

https://doi.org/10.3853/j.0067-1967.18.1984.380

Vader W. \& Krapp-Schickel G. 1996. Redescription and biology of Stenothoe brevicornis Sars (Amphipoda: Crustacea), an obligate associate of the sea anemone Actinostola callosa (Verrill). Journal of Natural History 30: 51-66. https://doi.org/10.1080/00222939600770041 
Vader W. \& Lønning S. 1973. Physiological adaptations in associated amphipods. A comparative study of tolerance to sea anemones in four species of Lysianassidae. Sarsia 53: 29-40.

https://doi.org/10.1080/00364827.1973.10411245

Vader W., Johnsen J.R. \& Berge J. 2005. Studies on the genus Onisimus Boeck, 1871 (Crustacea, Amphipoda, Lysianassoidea, Uristidae), Part I. The brevicaudatus and sextonae species groups. Organisms, Diversity \& Evolution 5: 161-164, Electr Suppl. 7: 1-48. https://doi.org/10.1016/j.ode.2004.08.002

Zimina O.L., Strelkova N.A. \& Lyubina O.S. 2019. Species composition and peculiarities of the distribution of benthic Peracarida (Crustacea, Malacostraca) in the Barents Sea, based on surveys 2003-2008. Biology Bulletin (Zoologichesky Zhurnal) 46: 864-885. https://doi.org/10.1134/S1062359019080181

Manuscript received: 1 July 2020

Manuscript accepted: 17 September 2020

Published on: 18 November 2020

Topic editor: Rudy Jocqué

Desk editor: Pepe Fernández

Printed versions of all papers are also deposited in the libraries of the institutes that are members of the EJT consortium: Muséum national d'histoire naturelle, Paris, France; Meise Botanic Garden, Belgium; Royal Museum for Central Africa, Tervuren, Belgium; Royal Belgian Institute of Natural Sciences, Brussels, Belgium; Natural History Museum of Denmark, Copenhagen, Denmark; Naturalis Biodiversity Center, Leiden, the Netherlands; Museo Nacional de Ciencias Naturales-CSIC, Madrid, Spain; Real Jardín Botánico de Madrid CSIC, Spain; Zoological Research Museum Alexander Koenig, Bonn, Germany; National Museum, Prague, Czech Republic. 